\title{
Faunal diversity of Cladocera (Crustacea: Branchiopoda) of Nokrek Biosphere Reserve, Meghalaya, northeastern India
}

\author{
B.K. Sharma ${ }^{1} \&$ Sumita Sharma ${ }^{2}$ \\ 1,2 Freshwater Biology Laboratory, Department of Zoology, North-Eastern Hill University, Permanent Campus, Shillong, Meghalaya \\ 793022, India \\ Email: ${ }^{1}$ profbksharma@gmail.com (corresponding author), ${ }^{2}$ sumitasharma.nehu@gmail.com
}

Date of publication (online): 26 October 2011 Date of publication (print): 26 October 2011 ISSN $0974-7907$ (online) | 0974-7893 (print)

Editor: Stephen C. Weeks

Manuscript details:

Ms \# 02637

Received 03 December 2010

Final received 04 August 2011

Finally accepted 01 October 2011

Citation: Sharma, B.K. \& S. Sharma (2011). Faunal diversity of Cladocera (Crustacea: Branchiopoda) of Nokrek Biosphere Reserve, Meghalaya, northeastern India. Journal of Threatened Taxa 3(10): 2120-2127

Copyright: () B.K. Sharma \& Sumita Sharma 2011. Creative Commons Attribution 3.0Unported License. JoTT allows unrestricted use of this article in any medium for non-profit purposes, reproduction and distribution by providing adequate credit to the authors and the source of publication.

Author Details: Drs. B.K SHARMA and SUMITA SHARMA specialize in aquatic biodiversity and limnology and have made significant contributions to faunal diversity, biogeography and ecology of freshwater zooplankton of India. The corresponding author is a Professor in Department of Zoology and Dean, School of Life Sciences, NEHU, Shillong.

Author Contribution: This study is the result of work undertaken by the authors at the Freshwater Biology Laboratory, Department of Zoology, North-Eastern Hill University, Shillong.

Acknowledgements: This study is a part of the "University with Potential for Excellence Program (Focused Area: Biosciences) of NorthEastern Hill University, Shillong. Thanks are due to the Head, Department of Zoology and the Coordinator (UPE Biosciences), North-Eastern Hill University, Shillong for necessary facilities. The permission granted by the Conservator of Forests, Meghalaya is sincerely acknowledged. The authors are thankful to an anonymous reviewer for useful suggestions.

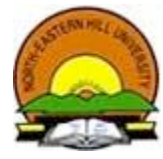

North-Eastern Hill University (University with Potential for Excellence)

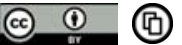

OPEN ACCESS | FREE DOWNLOAD
Abstract: Thirty-four species of Cladocera, belonging to 24 genera and seven families, documented from the Nokrek Biosphere Reserve of Meghalaya indicate fairly speciose and diverse taxocoenosis and comprise $57.7 \%$ of species known from this state. Coronatella anodonta is the first confirmed report from India and two species are new records from Meghalaya. Disperalona caudata is an interesting Australasian element and a number of species show regional distributional importance. The Cladocera of the Nokrek Biosphere Reserve show tropical characteristics with Cosmopolitan > Cosmotropical species, and are characterized by a distinct richness of the littoralperiphytonic members of the Chydoridae as well as a paucity of limnetic elements. The species richness of Cladocera in various localities ranges between 11-24 (15 \pm 3$)$ species.

Keywords: Alpha diversity, conservation area, India, micro-crustaceans.

\section{INTRODUCTION}

The systematic studies on Indian freshwater Cladocera were initiated by Baird (1860) but there is yet limited information on faunal and ecosystem diversity of these entomostracous crustaceans from different states of India in general (Sharma \& Michael 1987; Michael \& Sharma 1988; Sharma 1991) and in aquatic ecosystems of its conservation areas in particular. The studies on occurrence and distribution of these fishfood organisms in aquatic biotopes of conservation areas of northeastern India are limited to the reports from two Ramsar sites (Sharma \& Sharma $2008,2009)$ and two preliminary lists from Meghalaya by Hattar et al. (2004) and Sharma (2010a). This pioneering study on Cladoceran alpha diversity of the Nokrek Biosphere Reserve, Meghalaya is interesting in view of the paucity of biodiversity studies of this area. An inventory of the documented species is presented. Comments are made on the biogeographically interesting species as well as on the richness, nature and composition of Cladoceran fauna.

\section{MATERIALS AND METHODS}

The present study is a part of our investigations on faunal diversity of zooplankton of the Nokrek Biosphere Reserve (NBR) which is spread over parts of East, West and South Garo Hills districts of the state of Meghalaya, northeastern India (Fig. 1). It was declared a national park in 1997 and was designated a biosphere reserve in May, 2009. NBR 


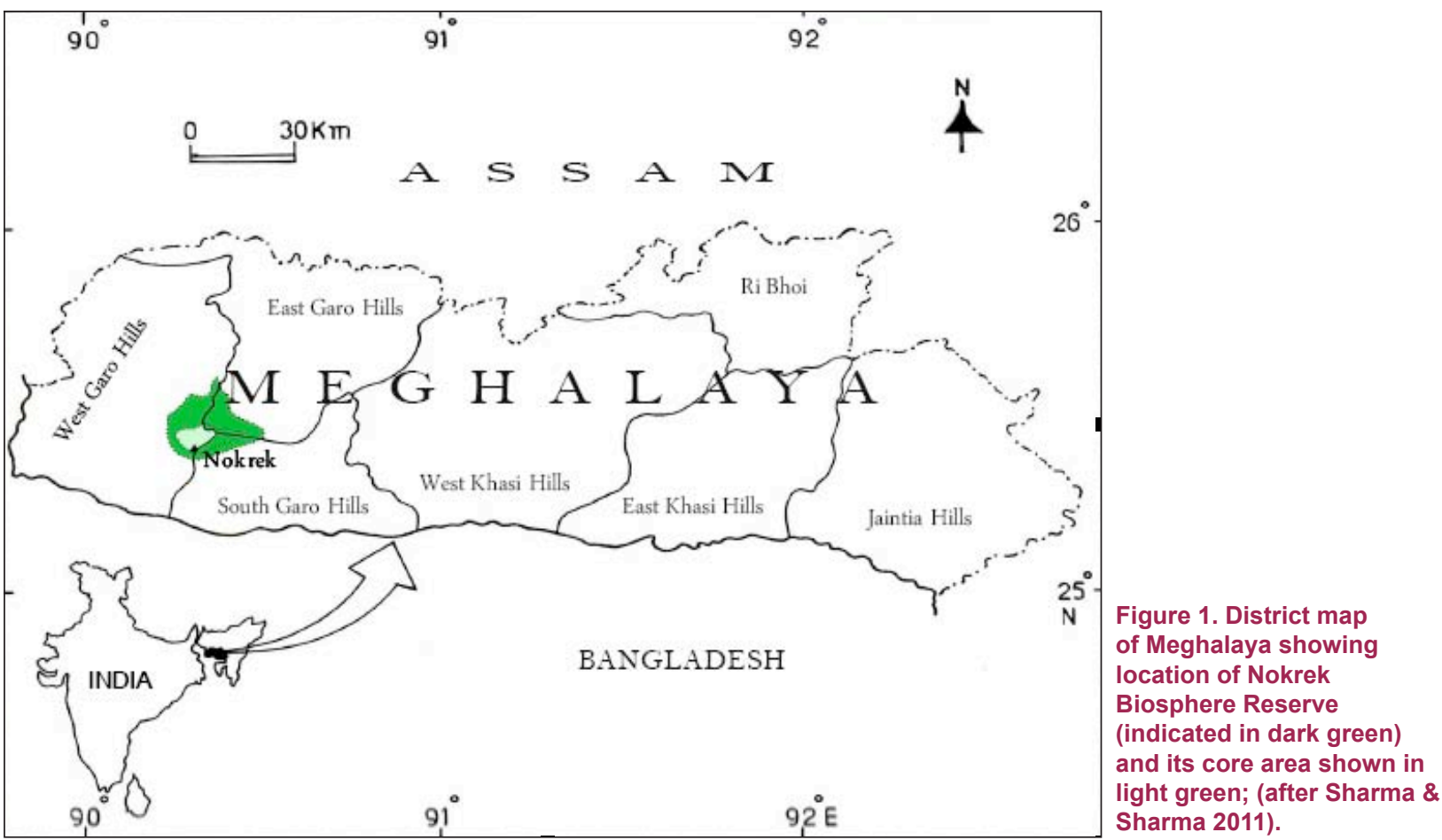

abounds in various wildlife including elephants, hoolock gibbons, rare varieties of birds and pheasants, rare orchids and is a 'National Citrus Gene Sanctuary' to a very rare endemic species of Citrus indica (locally called 'memang narang' or 'orange of the spirits').

One hundred and ten qualitative plankton samples were collected from 33 localities (four localities only partially sampled) of the Nokrek Biosphere Reserve $\left(25^{\circ} 21^{\prime}-25^{\circ} 34^{\prime} \mathrm{N}\right.$ \& 90 9014'-90 $\left.20^{\circ} \mathrm{E}\right)$, during July and September 2009 and January 2010, by towing a nylobolt plankton net (\#55 $\mathrm{m}$ ) and were preserved in $5 \%$ formalin. The sampled biotopes, in this otherwise hilly terrain, include shallow rain-fed water bodies and some perennial ponds, often with filamentous algae, semi-terrestrial vegetation and a few with Eichhornia crassipes. All the samples were screened with a wildstereoscopic binocular microscope and the cladocerans were isolated. Permanent mounts of different species made in a Polyvinyl-alcohol lactophenol mixture were examined with a Leica DM 1000image analyzer. The Cladocera were identified following Smirnov (1971, 1974, 1996), Michael \& Sharma (1988), Sharma \& Sharma (1999, 2008) and Van Damme et al. (2010). An account of faunal diversity of Rotifera present in our collections was published recently by Sharma \& Sharma (2011).

\section{RESULTS}

The details of the sampled localities of the NBR are given in Table 1 along with the number of species collected from each locality. In addition, Table 2 includes a systematic list of the Cladocera examined in this study.

\section{DISCUSSION}

Thirty-four species of Cladocera observed in our collections from the NBR reveal the fairly speciose nature of these micro-crustaceans. Our report is important in view of a total of 58 species of this group known to date from the state of Meghalaya (vide Sharma \& Sharma 1999; Sharma 2008, 2010b). The recorded richness also assumes importance in light of a conservative estimate (Fernando \& Kanduru 1984; Sharma \& Michael 1987; Sharma 1991) of the occurrence of up to 60-65 species of Cladocera from tropical and subtropical parts of India. Coronatella anodonta is the first confirmed report from India; Disperalona caudata and Chydorus ventricosus are new records from Meghalaya. Our samples are characterized by rich generic diversity: out of 
Table 1. List of the sampled localities

\begin{tabular}{|c|c|c|c|}
\hline Dates of collection & Locality & Location & Species recorded (vide list: Table 2) \\
\hline \multicolumn{4}{|c|}{ East Garo Hills } \\
\hline $\begin{array}{l}\text { 12.vii.2009, 20.ix.2009, } \\
\text { 02.i.2010, 27.i.2010 }\end{array}$ & Manchuri Chiring & $\begin{array}{l}25^{\circ} 34^{\prime} 26.2^{\prime \prime} \mathrm{N} \\
90^{\circ} 18^{\prime} 44.1^{\prime \prime} \mathrm{E}\end{array}$ & $1,2,3,5,8,9,10,13,15,17,21,22,24,28,30,32,34=17$ \\
\hline $\begin{array}{l}\text { 12.vii.2009, 20.ix.2009, } \\
\text { 02.i.2010, 27.i.2010 }\end{array}$ & Dinamangre & $\begin{array}{l}25^{0} 33^{\prime} 32.0 ” \mathrm{~N} \\
90^{0} 19^{\prime} 13.8^{\prime \prime} \mathrm{E}\end{array}$ & $1,2,3,4,6,8,10,11,13,16,17,18,23,24,25,30,31,32,33=19$ \\
\hline $\begin{array}{l}\text { 12.vii.2009, 20.ix.2009, } \\
\text { 02.i.2010, 27.i.2010 }\end{array}$ & Dinamangre I & $\begin{array}{l}25^{\circ} 33^{\prime} 37.9^{\prime \prime} \mathrm{N} \\
90^{\circ} 19^{\prime} 29.1^{\prime \prime} \mathrm{E}\end{array}$ & $2,4,6,8,9,10,11,12,13,17,21,22,24,27,28,32=16$ \\
\hline $\begin{array}{l}\text { 12.vii.2009, 20.ix.2009, } \\
\text { 02.i.2010, 27.i.2010 }\end{array}$ & Chirapat Chiring & $\begin{array}{l}25^{\circ} 33^{\prime} 08.2^{\prime \prime} \mathrm{N} \\
90^{\circ} 22^{\prime} 42.1^{\prime \prime} \mathrm{E}\end{array}$ & $\begin{array}{l}1,2,3,4,5,7,8,9,10,13,14,17,19,20,21,22,24,25,26,28,29,30, \\
32,34=24\end{array}$ \\
\hline $\begin{array}{l}\text { 12.vii.2009, 20.ix.2009, } \\
\text { 02.i.2010, 27.i.2010 }\end{array}$ & Chirapat & $\begin{array}{l}25^{\circ} 33^{\prime} 06.9^{\prime \prime} \mathrm{N} \\
90^{\circ} 22^{\prime} 41.6^{\prime \prime} \mathrm{E}\end{array}$ & $2,3,5,8,9,10,13,17,21,24,30,33=12$ \\
\hline 12.vii.2009, 27.i.2010 & Chirapat I & $\begin{array}{l}25^{\circ} 33^{\prime} 07.7^{\prime \prime} \mathrm{N} \\
90^{\circ} 22^{\prime} 42.3^{\prime \prime} \mathrm{E}\end{array}$ & $2,5,8,9,10,13,17,21,24,30,=10$ \\
\hline $\begin{array}{l}\text { 13.vii.2009, 19.ix.2009, } \\
\text { 03.i.2010, 28.i.2010 }\end{array}$ & Mandal Chiring & $\begin{array}{l}25^{\circ} 31 ' 29.2 " \mathrm{~N} \\
90^{\circ} 21^{\prime} 58.9^{\prime \prime} \mathrm{E}\end{array}$ & $\begin{array}{l}1,2,3,4,5,6,8,9,10,11,13,16,17,18,20,23,24,25,30,31,32,33 \\
=22\end{array}$ \\
\hline $\begin{array}{l}\text { 13.vii.2009, 19.ix.2009, } \\
\text { 03.i.2010, 28.i.2010 }\end{array}$ & Mandal Chiring I & $\begin{array}{l}25^{0} 30^{\prime} 28.9^{\prime \prime} \mathrm{N} \\
90^{\circ} 21^{\prime} 57.2 \text { 'E }\end{array}$ & $1,2,4,5,6,8,9,10,11,13,17,18,21,24,25,30,31,32=18$ \\
\hline $\begin{array}{l}\text { 13.vii.2009, 19.ix.2009, } \\
\text { 03.i.2010, 28.i.2010 }\end{array}$ & Mandalgre & $\begin{array}{l}25^{0} 30^{\prime} 31.2 " \mathrm{~N} \\
90^{\circ} 21^{\prime} 58.1^{\prime \prime} \mathrm{E}\end{array}$ & $1,4,7,8,9,10,13,15,17,19,21,24,28,32,34=15$ \\
\hline 13.vii.2009, 19.ix.2009 & Mandalgre I & $\begin{array}{l}25^{0} 30^{\prime} 31.2 " \mathrm{~N} \\
90^{\circ} 21^{\prime} 58.1^{\prime \prime} \mathrm{E}\end{array}$ & $2,5,8,11,13,17,19,22,24,26,32=11$ \\
\hline $\begin{array}{l}\text { 13.vii.2009, 19.ix.2009, } \\
\text { 03.i.2010, 28.i.2010 }\end{array}$ & Daribokgre & $\begin{array}{l}25^{0} 29^{\prime} 27.9^{\prime \prime} \mathrm{N} \\
90^{\circ} 19^{\prime} 55.5^{\prime \prime} \mathrm{E}\end{array}$ & $2,4,5,7,8,9,13,14,15,17,18,21,22,24.28,39,32=17$ \\
\hline $\begin{array}{l}\text { 13.vii.2009, 19.ix.2009, } \\
\text { 03.i.2010, 28.i.2010 }\end{array}$ & Adugre & $\begin{array}{l}25^{0} 28^{\prime} 55.0 " \mathrm{~N} \\
90^{\circ} 29^{\prime} 10.9^{\prime \prime} \mathrm{E}\end{array}$ & $1,2,7,8,9,10,11,13,17,18,19,25,30,32,34=15$ \\
\hline \multicolumn{4}{|c|}{ West Garo Hills } \\
\hline $\begin{array}{l}\text { 14.vii.2009, 21.ix.2009, } \\
\text { 05.i.2010, 29.i.2010 }\end{array}$ & Kalupara Chiring & $\begin{array}{l}25^{0} 34^{\prime} 15.2 " \mathrm{~N} \\
90^{0} 14^{\prime} 04.1^{\prime \prime} \mathrm{E}\end{array}$ & $4,5,6,8,10,12,13,17,21,22,24,25,28,29 . .30,32,33=17$ \\
\hline $\begin{array}{l}\text { 14.vii.2009, 21.ix.2009, } \\
\text { 05.i.2010, 29.i.2010 }\end{array}$ & Manchuri Chiring & $\begin{array}{l}25^{0} 33^{\prime} 25.8 ” \mathrm{~N} \\
90^{0} 18^{\prime} 44.0 " \mathrm{E}\end{array}$ & $1,2,7,8,9,11,13,17,18,21,22,24,27,30,31,32=16$ \\
\hline $\begin{array}{l}\text { 14.vii.2009, 21.ix.2009, } \\
\text { 05.i.2010, 29.i.2010 }\end{array}$ & Tosekgre & $\begin{array}{l}25^{0} 32^{\prime} 54.0 " \mathrm{~N} \\
90^{0} 17^{\prime} 59.0 " \mathrm{E}\end{array}$ & $2,5,8,9,10,12,16,17,21.25,28,30,32,34=14$ \\
\hline $\begin{array}{l}\text { 14.vii.2009, 21.ix.2009, } \\
\text { 05.i.2010, 29.i.2010 }\end{array}$ & Matchurigre & $\begin{array}{l}25^{0} 32^{\prime} 53.3 " \mathrm{~N} \\
90^{0} 17^{\prime} 37.9^{\prime \prime} \mathrm{E}\end{array}$ & $4,5,8,9,11,13,17,18,21,22,24,26,30,32,34=15$ \\
\hline 14.vii.2009, 29.i.2010 & Matchurigre I & $\begin{array}{l}25^{0} 32^{\prime} 55.3^{\prime \prime} \mathrm{N} \\
90^{0} 16^{\prime} 59.1^{\prime \prime} \mathrm{E}\end{array}$ & $2,6,8,10,13,16,17,21,25,30,32=11$ \\
\hline $\begin{array}{l}\text { 15.vii.2009, 22.ix.2009, } \\
\text { 06.i.2010, } 30 . \mathrm{i} .2010\end{array}$ & Sasategre Chiring & $\begin{array}{l}25^{0} 28^{\prime} 10.0 ” \mathrm{~N} \\
90^{0} 15^{\prime} 40.1^{\prime \prime} \mathrm{E}\end{array}$ & $\begin{array}{l}1,2,3,4,6,8,9,10,11,13,15,17,19,20,21,22,24,26,30,32,33 \\
=21\end{array}$ \\
\hline 15.vii.2009, 29.i.2010 & Sasategre Chiring I & $\begin{array}{l}25^{0} 28^{\prime} 40.0^{\prime \prime} \mathrm{N} \\
90^{0} 16^{\prime} 10.3^{\prime \prime} \mathrm{E}\end{array}$ & $2,8,10,11,12,17,22,24,28,30,32=11$ \\
\hline $\begin{array}{l}\text { 15.vii.2009, 22.ix.2009, } \\
\text { 06.i.2010, } 30 . \mathrm{i} .2010\end{array}$ & Sasategre & $\begin{array}{l}25^{0} 28^{\prime} 10.0 ” \mathrm{~N} \\
90^{0} 15^{\prime} 40.1^{\prime \prime} \mathrm{E}\end{array}$ & $2,4,7,8,11,13,17,19,21,22,24,25,29,30,34=15$ \\
\hline $\begin{array}{l}\text { 15.vii.2009, 22.ix.2009, } \\
\text { 06.i.2010, 30.i.2010 }\end{array}$ & Sangkenigiri & $\begin{array}{l}25^{0} 24^{\prime} 13.2 " \mathrm{~N} \\
90^{0} 14^{\prime} 39.0 " \mathrm{E}\end{array}$ & $1,2,8,9,10,11,15,17,21,22,24,28,31,32=14$ \\
\hline $\begin{array}{l}\text { 15.vii.2009, 22.ix.2009, } \\
\text { 06.i.2010, 30.i.2010 }\end{array}$ & Dapgre & $\begin{array}{l}25^{0} 23^{\prime} 23.9 ” \mathrm{~N} \\
90^{0} 16^{\prime} 27.3^{\prime \prime} \mathrm{E}\end{array}$ & $3,4,7,8,9,10,13,17,21,23,25,28,32,34=14$ \\
\hline 15.vii.2009, 22.ix.2009 & Dapgre I & $\begin{array}{l}25^{0} 23^{\prime} 24.5^{\prime \prime} \mathrm{N} \\
90^{0} 17^{\prime} 38.1 \text { 'E }\end{array}$ & $2,4,6,10,11,12,17,22,24,32=10$ \\
\hline $\begin{array}{l}\text { 15.vii.2009, 22.ix.2009, } \\
\text { 06.i.2010, 30.i.2010 }\end{array}$ & Rongram Chiring & $\begin{array}{l}25^{0} 22^{\prime} 54.5^{\prime \prime} \mathrm{N} \\
90^{0} 17^{\prime} 01.8^{\prime \prime} \mathrm{E}\end{array}$ & $2,4,5,8,9,10,13,17,21.22,25,28,30,32,34=15$ \\
\hline \multicolumn{4}{|c|}{ South Garo Hills } \\
\hline $\begin{array}{l}\text { 11.vii.2009, 23.ix.2009, } \\
\text { 07.i.2010, 31.i.2010 }\end{array}$ & Reng Sangre & $\begin{array}{l}25^{0} 24^{\prime} 52.11^{\prime \prime} \mathrm{N} \\
90^{0} 16^{\prime} 09.0^{\prime \prime} \mathrm{E}\end{array}$ & $1,2,4,7,10,13,14,16,17,22,27,28,30,32=14$ \\
\hline $\begin{array}{l}\text { 11.vii.2009, 23.ix.2009, } \\
\text { 07.i.2010, 31.i.2010 }\end{array}$ & Reng Sangre I & $\begin{array}{l}25^{\circ} 24^{\prime} 12.6^{\prime \prime} \mathrm{N} \\
90^{0} 16^{\prime} 39.2^{\prime \prime} \mathrm{E}\end{array}$ & $2,5,7,8,9,11,13,17,18,21,24,25,2830,34=15$ \\
\hline
\end{tabular}




\begin{tabular}{|c|c|c|c|}
\hline Dates of collection & Locality & Location & Species recorded (vide list: Table 2) \\
\hline $\begin{array}{l}\text { 11.vii.2009, 23.ix.2009, } \\
\text { 07.i.2010, 31.i.2010 }\end{array}$ & Mitapgre & $\begin{array}{l}25^{\circ} 23^{\prime} 50.9^{\prime \prime} \mathrm{N} \\
90^{\circ} 16^{\prime} 27.3^{\prime \prime} \mathrm{E}\end{array}$ & $1,2,4,5,8,9,10,13,17,21,22,24,39,32,33=15$ \\
\hline $\begin{array}{l}\text { 11.vii.2009, 23.ix.2009, } \\
\text { 07.i.2010, 31.i.2010 }\end{array}$ & Mitapgre I & $\begin{array}{l}25^{\circ} 23^{\prime} 57.0^{\prime \prime} \mathrm{N} \\
90^{\circ} 16^{\prime} 27.8^{\prime \prime} \mathrm{E}\end{array}$ & $2,5,8,9,10,12,16,17,21.25,28,39,32,34=14$ \\
\hline $\begin{array}{l}\text { 11.vii.2009, 23.ix.2009, } \\
\text { 07.i.2010, 31.i.2010 }\end{array}$ & Nengirang Chiring & $\begin{array}{l}25^{\circ} 21^{\prime} 00.5^{\prime \prime} \mathrm{N} \\
90^{\circ} 25^{\prime} 58.9^{\prime \prime} \mathrm{E}\end{array}$ & $\begin{array}{l}1,4,6,9,10,13,17,18,23,24,28,30,32 \\
=13\end{array}$ \\
\hline 08.i.2010 & Chokpot Bibagre * & - & $4,8,10,12,17,24=6$ \\
\hline 08.i.2010 & Chokpot * & - & $5,7,10,11,19,31=6$ \\
\hline 08.i.2010 & Chokpot Market * & - & $4,9,10,17,32=5$ \\
\hline 08.i.2010 & Gilmatkolgre* & - & $2,6,10,13,17,30,=6$ \\
\hline
\end{tabular}

*only representative collections, hence, not considered for richness comparisons

Table 2. Systematic list of the examined Cladocera

\section{Super-class: Crustacea}

Class: Branchiopoda

Super-order: Cladocera (s. str.)

Ctenopoda: Sididae

1. Diaphanosoma excisum Sars, 1885

2. D. sarsi Richard, 1895

3. Pseudosida bidentata Herrick, 1884

\section{Anomopoda: Daphniidae}

4. Ceriodaphnia cornuta Sars, 1885

5. Scapholeberis kingi Sars, 1901

6. Simocephalus (Echinocaudus) acutirostratus (King, 1853)

7. S. (Coronocephalus) serrulatus (Koch, 1841)

8. S. (s. str.) mixtus Sars, 1903

\section{Bosminidae}

9. Bosmina longirostris (O. F. Muller, 1776)

10. Bosminopsis deitersi Richard, 1895

\section{Moinidae}

11. Moinodaphnia macleayi (King, 1853)

\section{Macrothricidae}

12. Macrothrix spinosa King, 1853

13. M. triserialis (Brady, 1886)

\section{Ilyocryptidae}

14. Ilyocryptus spinifer Herrick, 1882

\section{Chydoridae: Chydorinae}

15. Alonella clathratula Sars, 1886

16. A. excisa (Fischer, 1854)

17. Chydorus sphaericus (O. F. Muller, 1776)

18. C. ventricosus Daday, 1898

19. Dadaya macrops (Daday, 1898)

20. Disperalona caudata Smirnov, 1996

21. Dunhevedia crassa King, 1853

22. Picripleuroxus similis Vavra, 1900

23. Pseudochydorus globosus (Baird, 1843)

\section{Aloninae}

24. Alona costata Sars, 1862

25. A. guttata guttata Sars, 1862

$$
\text { A. guttata tuberculata Kurz, } 1875
$$

26. A. pulchella King, 1895

27. A. quadrangularis (O. F. Muller, 1776)

28. Camptocercus uncinatus Smirnov, 1971

29. Coronatella anodonta (Daday, 1905)

30. C. rectangula (Sars, 1862)

31. Graptoleberis testudinaria (Fischer, 1854)

32. Karualona karua (King, 1853)

33. Leberis davidi (Richard, 1895)

34. Oxyurella singalensis (Daday, 1862)
30 genera of Cladocera recorded from the state of Meghalaya (Sharma \& Sharma 1999; Sharma 2008), 24 genera are represented in this study. Further, among eight families of freshwater Cladocera known from India, seven are represented in our collections: the phylogenetic stem Ctenopoda belong to one family (i.e., Sididae) while Anomopoda are represented by six families (Daphniidae - Bosminidae - Moinidae Macrothricidae - Ilyocryptidae - Chydoridae). The species-rich nature, as well as the rich higher diversity (genera and families), reflects the fairly diverse composition of the cladoceran communities of the NBR. This salient feature concurs with previous work on the faunal diversity of the Rotifera of this biosphere reserve (Sharma \& Sharma 2011).

Incomplete Cladocera inventories from the conservation areas of India may not permit meaningful comparison with our report. This generalization is evident from the reports of only one species from the Kanha National Park, Madhya Pradesh (Rane 1984) and nine species from the Saipung Wild Life Sanctuary / Narpuh Reserve Forest of Meghalaya (Hattar et al. 2004). The faunal diversity is distinctly richer than the 21 species (Sharma 2010a) examined from the Baghmara Reserve Forest of Meghalaya. The richness, however, broadly compares with the reports of 31 species from the Nagerhole National Park, Tamil Nadu (Raghunathan \& Rane 2001), 29 species from the Melghat Tiger Reserve, Maharashtra (Rane 2005a) and 39 species each from the Keoladelo National Park, Rajasthan (Venkataraman 1992), as well as the Nathsagar wetland and the Jaikwadi Bird Sanctuary, Maharashtra (Rane 2005b). On the other hand, the richness is distinctly lower than the reports of 45 (Sharma \& Sharma 2008) and 51 (Sharma \& 


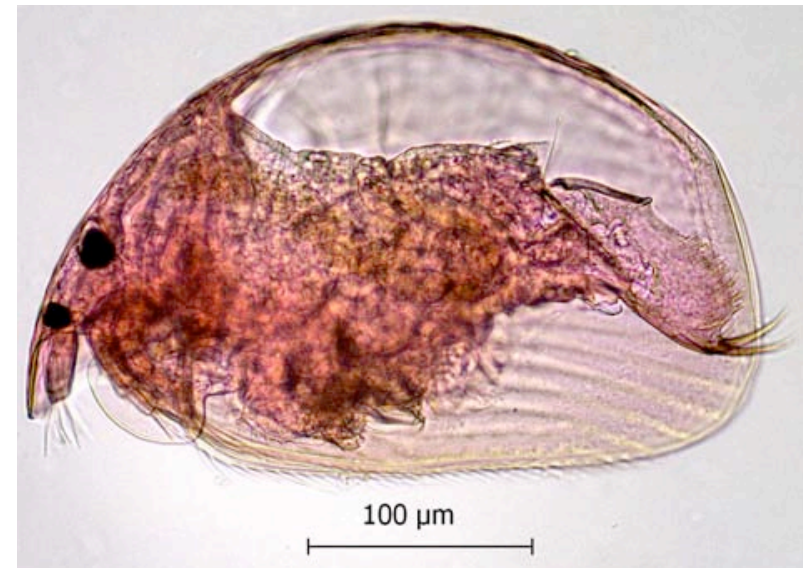

Image 1. Coronatella anodonta (Daday), parthenogenetic female, lateral view

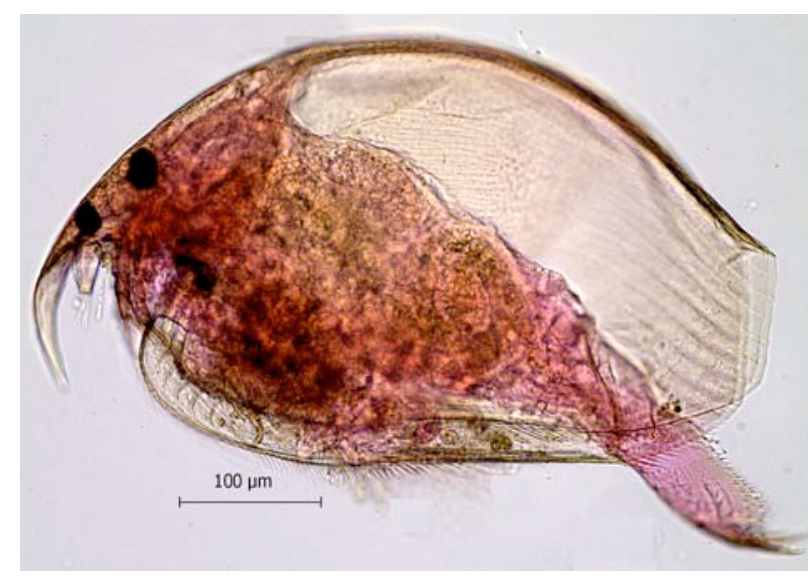

Image 3. Disperalona caudata Smirnov, parthenogenetic female, lateral view

Sharma 2009) species known from two Ramsar sites of India, namely Deepor Beel (Assam) and Loktak Lake (Manipur), respectively. However, we caution against over-emphasizing the importance of the stated comparisons without considering sampling intensity and the nature of the different ecosystems.

Daday (1905) described Alona anodonta from Lake Gregory, but his description and illustrations were not satisfactory (refer: Rajapaksa \& Fernando 1982). Rajapaksa \& Fernando (1982), in turn, recorded it from Sri Lanka with proper figures as $A$. cf. anodonta Daday, 1905. Brehm (1933) examined specimens without characteristic tubercles and described them as $A$. pseudoanodonta. The former was designated as $A$. pseudoanodonta anodonta and the latter as $A$. pseudoanodonta pseudoanodonta by Smirnov (1971). Van Damme et al. (2010) termed this treatment to be incorrect as anodonta is an earlier described species,

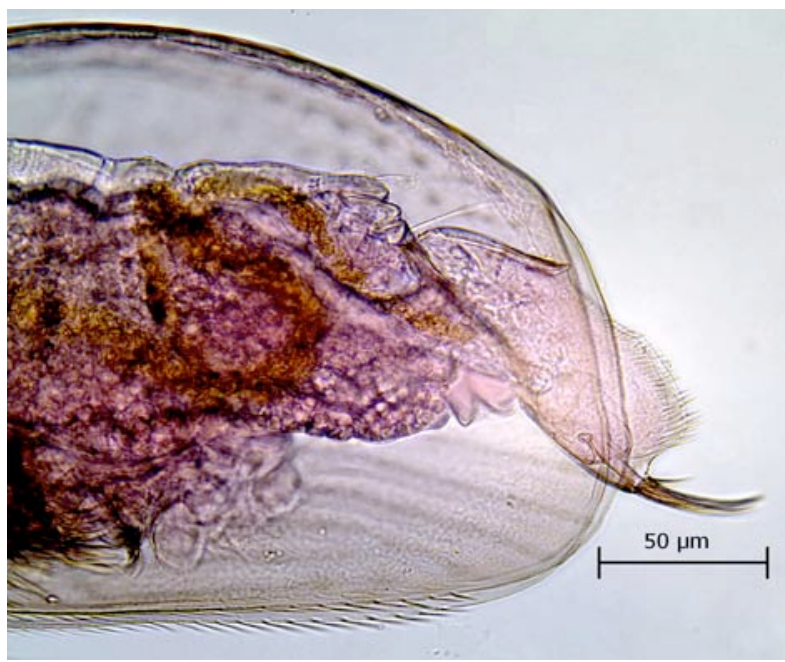

Image 2. Coronatella anodonta (Daday), postabdomen, lateral view

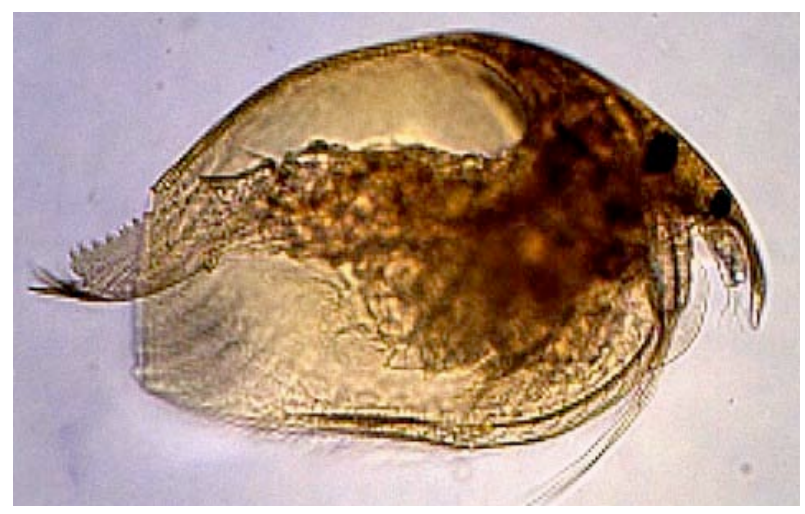

Image 4. Alonella clathratula Sars, parthenogenetic female, lateral view

and opined these to be different species which require more analysis. He also proposed to allocate them to the genus Coronatella. An earlier Indian report of Coronatella anodonta from the Keoladeo National Park (Venkataraman 1998), a Ramsar site, remains indeterminate because of the different shape of the diagnostic labrum as well as the shape and armature of its characteristic postabdomen and, hence, needs confirmation. Fernando \& Kanduru (1984) listed this species in their publication on the latitudinal distribution of Cladocera on the Indian subcontinent but lacked any indication of its occurrence in India. In view of the mentioned facts, the present study (Images $1 \& 2$ ) is the first confirmed report of Coronatella anodonta in India.

The Australasian Disperalona caudata (Image 3) is a biogeographically interesting species observed 


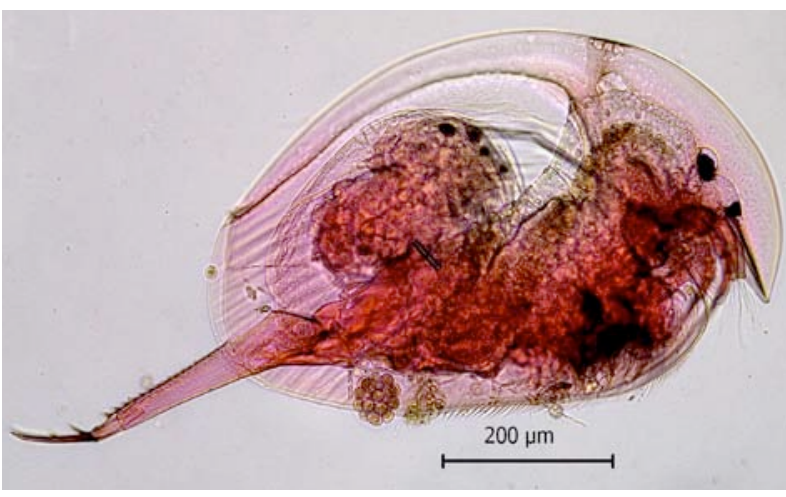

Image 5. Camptocercus uncinatus Smirnov, parthenogenetic female, lateral view

from the Nokrek Biosphere Reserve. Described from Australia, this species is known outside of Australia to this date only from Thailand and northeastern India; the latter report refers to its occurrence in Assam (Sharma \& Sharma 2007, 2008) while the present study extends its distributional range to the adjoining state of Meghalaya. Alonella clathratula (Image 4), A. pulchella, A. guttata tuberculata, Simocephalus serrulatus, Camptocercus uncinatus (Image 5), Chydorus ventricosus and Graptoleberis testudinaria (Image 6) are examples of regional distributional interest in India.

Amongst the stated species, Alonella clathratula was formerly treated as a subspecies of A. excisa by Smirnov (1971) while Smirnov (1996) subsequently resurrected its specific status based on an elongated body and postabdomen as well as a different distributional range. The former occurs in Australia, the Ethiopian and neotropical regions, and Java while A. excisa shows a cosmopolitan distribution. A. clathratula is apparently overlooked in the Indian works, until its reports from Bihar (Sharma \& Sharma 2001), Assam (Sharma \& Sharma 2008, 2010) and Meghalaya (Sharma 2010a). Alona guttata tuberculata, treated as a subspecies of A. guttata by Smirnov (1971), is distinctly characterized by rounded pits or tubercles on its head shield and valves. The former is known only from Europe, Columbia, and former USSR as against the nominate Alona guttata which apparently is a cosmopolitan species. A. guttata tuberculata is, however, recently documented from India from Meghalaya (Sharma 2008) and Assam (Sharma \& Sharma 2010). Simocephalus acutirostratus appears to occur in central India and southwards (Sharma

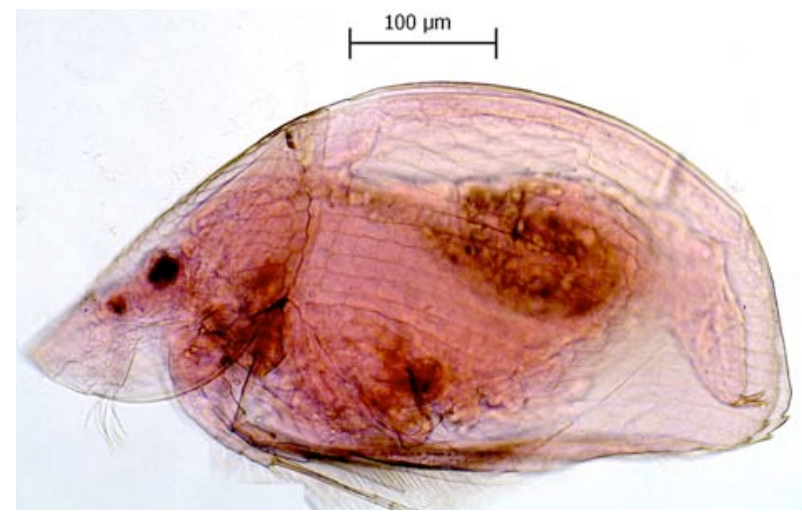

Image 6. Graptoleberis testudinaria (Fischer), parthenogenetic female, lateral view

1991) while $S$. serrulatus is so far only known from southern India, Assam and Meghalaya. The cosmopolitan Graptoleberis testudinaria shows a disjunct occurrence in India, with records from Kashmir, Uttaranchal, Meghalaya, Assam and Andhra Pradesh. Smirnov (1971) described Camptocercus uncinatus from Lake Nikolaevskoe (Russia) while Smirnov (1998) again provided a detailed description of this species to resolve taxonomic anomalies, anticipating its wider occurrence, and remarked on the need for re-examination of the reports supposed to be that of $C$. australis, in particular. The first confirmed record of $C$. uncinatus from the Indian subcontinent is provided by Sharma (2008) who proposed C. latikae, described by Rane (1985) from Madhya Pradesh, as its synonym. This species is so far known from this country from the states of Assam and Meghalaya. Chydorus ventricosus, an anomalous chydorid, was re-described by Rajapaksa \& Fernando (1986). This species is known from Sri Lanka, Java, Africa and South America while it is so far observed in this country from southern, central and western India. C. ventricosus is recently reported (Sharma \& Sharma 2010) from northeastern India from Assam and this study extends its distribution to the state of Meghalaya. Interestingly, the stated aspects indicate that the occurrence of Alona guttata tuberculata, Camptocercus uncinatus and Chydorus ventricosus is restricted to northeastern India. Alona davidi is assigned to the genus Leberis following Sinev et al. (2005).

The Chydoridae, the largest family of Cladocera, forms a main component (20 species, 58.8\%) of the 
reported species. This generalization concurs with the composition of the Indian Cladocera (Sharma 1991) and also with the faunas of various regions or states of this country. The chydorids essentially include the littoral-periphytonic species. On the contrary, the paucity of planktonic Cladocera, a distinctive feature of our study, is apparently attributed to a shallow ephemeral nature of the majority of water bodies in the study area and even the lack of distinct limnetic conditions in others. However, a few members of this category include Bosmina longirostris, Bosminopsis deitersi, Ceriodaphnia cornuta, and Moinodaphnia macleayi and these exhibit limited occurrences. Alona costata, Chydorus sphaericus, Diaphanosoma sarsi, Karualona karua, Macrothrix triserialis and Simocephalus mixtus show common occurrence and the rest of the listed species are observed in fewer samples.

Our collections show qualitative dominance of cosmopolitan species while cosmotropical and pantropical elements are well represented. In general, the cladoceran fauna of the NBR exhibits a 'tropical character'. The stated generalization is in broader conformity with the general composition of several tropical cladoceran communities (Fernando 1980; Fernando \& Kanduru 1984; Dussart et al. 1984; Sharma \& Michael 1987; Sharma 1991; Sharma \& Sharma 2008, 2009). The present study raises the cladoceran richness (58 species) known earlier from this state (vide Sharma \& Sharma 1999; Sharma 2008, 2010a) to 61 species, the highest recorded from any state of India, and is followed by the reports from Jammu \& Kashmir (59 species) $>$ West Bengal (52 species).

The limited collections examined by us from different localities (excluding four partially sampled localities of South Garo Hills) indicate total species

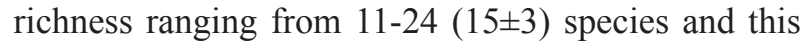
is fairly speciose. Peak richness observed in Chiring Chirapat is followed by the reports of 22 and 21 species from Mandal Chiring and Sasategre Chiring, respectively. In addition, various localities of East, West and South Garo Hills districts indicate broadly concurrent mean richness; i.e., between $16 \pm 3,14 \pm 3$ and $14 \pm 1$ species, respectively.

To sum up, the cladoceran fauna of the NBR is fairly rich and diverse, reflects a tropical character with cosmopolitan $>$ cosmotropical species, reveals certain biogeographically interesting species and is characterized by distinct richness of the littoralperiphytonic members of the Chydoridae as well a paucity of planktonic Cladocera. The fauna, however, still requires extensive future collections from the study area. Nevertheless, this study is an important contribution to our understanding of the aquatic biodiversity of the biosphere reserves and conservation areas of India.

\section{REFERENCES}

Baird, W. (1860). Description of the two new species of Entomostraceous Crustacea from India. Proceeding of the Zoological Society, London 213-234.

Brehm, V. (1933). Die Cladoceren der Deutschen Limnologischen Sunda-Expedition. Archive fur Hydrobiolologie (Suppliment) 11: 631-771.

Daday, E. (1905). Untersuchungen uber die SüsswasserMikrofauma Paraguays. Zoologica 18: 1-374.

Dussart, B.H., C.H. Fernando, J. Matsumura-Tundisi \& R.J. Shiel (1984). A review of systematics, distribution and ecology of tropical freshwater zooplankton. Hydrobiologia 113: 77-91.

Fernando, C.H. (1980). The freshwater zooplankton of Sri Lanka, with a discussion of tropical freshwater zooplankton composition. Internationale Revue Hydrobiologie 65: 411426.

Fernando, C.H. \& A. Kanduru (1984). Some remarks on the latitudinal distribution of Cladocera on the Indian subcontinent. Hydrobiologia 113: 69-76.

Hatter, S.J.S., N. Sen, R. Mathew \& S. Sharma (2004). Faunal diversity of Saipung Wild Life Sanctuary / Narpuh Reserve Forest, Jaintia Hills, Meghalaya. Conservation Area Series 21: 1-66. Zoological Survey of India, Kolkata.

Michael, R.G. \& B.K. Sharma (1988). Indian Cladocera (Crustacea: Branchiopoda: Cladocera). Fauna of India and adjacent countries series, Zoological Survey of India, Calcutta, 262pp.

Raghunathan, M.B. \& P.D. Rane (2001). Cladocera (Crustacea). In: Fauna of Nilgiri Biosphere Reserve: Fauna of Conservation Area Series 11: 31-37.

Rajapaksa, R. \& C.H. Fernando (1982). The Cladocera of Sri Lanka (Ceylon), with remarks on some species. Hydrobiologia 94: 49-69.

Rajapaksa, R. \& C.H. Fernando (1986). A review of the systematics and distribution of Chydorus ventricosus Daday, 1889, with the first description of the male and redescription of the species. Canadian Journal of Zoology 64: 818-832.

Rane, P. (1984). Occurrence of Pleuroxus similis Vavra (Cladocera: Crustacea) in Kanha National Park, India. Journal of the Bombay Natural History Society 45(1): $82-84$. 
Rane, P. (1985). A new species of the genus Camptocercus Baird, 1843 (Cladocera) from Madhya Pradesh, Central India. Crustaceana 48: 113-116.

Rane, P.D. (2005a). Cladocera (Crustacea), pp. 451-500. In: Fauna of Melghat Tiger Reserve: Fauna of Conservation Area Series 24. Zoological Survey of India, Kolkata.

Rane, P.D. (2005b). Crustacea: Cladocera, pp. 77-99. In: Fauna of Nathsagar wetland and Jaikwadi Bird Sanctuary, Wetland Ecosystem Series 7. Zoological Survey of India, Kolkata.

Sharma, B.K. (1991). Cladocera, pp. 205-223. In: Animal Resources of India: Protozoa to Mammalia: State of the Art. Zoological Survey of India, Calcutta.

Sharma, B.K. \& R.G. Michael (1987). Review of taxonomic studies on freshwater Cladocera from India with remarks on biogeography. Hydrobiologia 145: 29-33.

Sharma, B.K. \& S. Sharma (1999). Freshwater Cladocerans (Crustacea: Branchiopoda: Cladocera). Zoological Survey of India, Kolkata.State Fauna Series: Fauna of Meghalaya 4(9): 469-550.

Sharma, B.K. \& S. Sharma (2001). Contributions to the cladoceran fauna (Crustacea: Branchiopoda) of Bihar. Records of the Zoological Survey of India 99: 31-43.

Sharma, B.K. \& S. Sharma (2007). New records of two interesting chydorid cladocerans (Branchiopoda: Cladocera: Chydoridae) from the floodplain lakes of Assam, India. Zoo's Print Journal 22(8): 2799-2801.

Sharma, B.K. \& S. Sharma (2008). Faunal diversity of Cladocera (Crustacea: Branchiopoda) of Deepor beel, Assam (Northeast India) - A Ramsar site. Journal of the Bombay Natural History Society 105(2): 196-201.

Sharma, B. K. \& S. Sharma (2009). Faunal diversity of Cladocera (Crustacea: Branchiopoda) of Loktak Lake (a Ramsar site), Manipur (N.E. India). Journal of the Bombay Natural History Society 106(2): 156-161.

Sharma, B. K. \& S. Sharma (2010). Taxonomic notes on some interesting Cladocerans (Crustacea: Branchiopoda: Cladocera) from Assam (N.E. India). Records of Zoological Survey of India 110(2): 39-47.

Sharma, B.K. \& S. Sharma (2011). Faunal diversity of Rotifers (Rotifera: Eurotatoria) of Nokrek Biosphere Reserve, Meghalaya, India. Journal of Threatened Taxa 3(2): 1535-1541.
Sharma, S. (2008). Notes on some rare and interesting Cladocerans (Crustacea: Branchiopoda) from Meghalaya. Records of the Zoological Survey of India 108(2): 111122.

Sharma, S. (2010a). Cladocera (Crustacea: Branchiopoda), pp. 25-33. In: Faunal diversity of Baghmara Reserve Forest, Meghalaya. Fauna of Conservation area series 44. Zoological Survey of India, Kolkata.

Sharma, S. (2010b). Micro-faunal diversity of Cladocerans (Crustacea, Branchiopoda, Cladocera) in rice field ecosystems of Meghalaya. Records of the Zoological Survey of India 110(1): 35-45.

Sinev, A.Y., K. Van Damme \& A.A. Kotov (2005). Redescription of tropical-temperate cladocerans Alona diaphana King, 1853 and Alona davidi Richard, 1895 and their translocation to Leberis Smirnov, 1989 (Branchiopoda: Anomopoda: Chydoridae). Arthropoda Selecta 14(3): 183205.

Smirnov, N.N. (1971). The World Chydorid Fauna (in Russian). USSR Academy of Sciences, Zoological Institute Nova Series 101: 539pp. Leningrad.

Smirnov, N. N. (1974). The World Macrothricidae (in Russian). USSR Academy of Sciences, Zoological Institute Nova Series 104pp. Leningrad.

Smirnov, N.N.(1996). Cladocera: The Chydorinae and Sayciinae (Chydoridae) of the World In: Dumont, H.J. \& T. Nogrady (eds.). Guides to Identification of the Microinvertebrates of the Continental Waters of the World: 11. SPB Academic Publishing by Amsterdam, The Netherlands.

Smirnov, N.N. (1998). A revision of the genus Camptocercus (Anomopoda, Chydoridae, Aloninae). Hydrobiologia 386: 63-83.

Van Damme, K.V., A. A. Kotov \& H. J. Dumont (2010). A checklist of names in Alona Baird 1843 (Crustacea: Cladocera: Chydoridae) and their current status: an analysis of the taxonomy of a lump genus. Zootaxa 2330: 1-63.

Venkataraman, K. (1992). I. Cladocera of Keoladeo National Park, Bharatpur and its environs. Journal of the Bombay Natural History Society 89(1): 17-26.

Venkataraman, K. (1998). Three new records of Cladocera (Crustacea) from India. Journal of the Bombay Natural History Society 95(3): 527-530. 